\title{
New Diagnosis Diabetes and Deep Venous Thrombosis with Glucagonoma Cases; Case Report
}

\author{
(D) Tahsin KARAASLAN, iD Cumali KARATOPRAK
}

Bezmialem Vakif University Faculty of Medicine, Department of General Surgery, İstanbul, Turkey

\begin{abstract}
Glucagonomas; is a rare neuroendocrine tumor originating from alpha cells of the pancreas. Glucagonoma syndrome is a paraneoplastic entity known as diarrhea, weight loss, stomatitis, thrombosis, diabetes, and necrotizing migratory erythema. It is difficult to come to mind in the differential diagnosis with the very rarely seen and little known reason. We also wanted to present a patient with bilateral deep vein thrombosis and a new diagnosis of diabetes that we were difficult to diagnose.
\end{abstract}

Keywords: Deep ven thrombosis, new diagnosis diabetes, glukagonoma, diarrhea

\section{Introduction}

Neuroendocrine tumors (NETs) are the tumors originating from the neuroendocrine system in any part of the body. NETs are rare tumors that are mostly benign but may also be aggressive. Today, NETs are divided into two groups as pancreatic NETs and other NETs (1). 60-90\% of NETs occur in the gastrointestinal tract and pancreatic system. They are rarely seen in other organs (lung, adrenal gland, thymus, bladder, ovary, testis) (2). Pancreatic NETs, $90-95 \%$ of which are insulinoma and gastrinoma, constitute $7 \%$ of all NETs. Glucagonoma constitutes only $4 \%$ of pNETs (3). $80 \%$ of glucagonomas are malignant. It is often sporadic and is associated with genetic factors in $20 \%$ of cases (MEN1). Glucagonomas may present with migratory necrotic skin rash (dermatitis), diabetes, depression, diarrhea (4D syndrome), glossitis, stomatitis, angular cheilitis and severe weight loss (4). We present the case because it is a rare entity.

\section{Case Report}

Our case was a 72-year-old male patient. The patient was brought to the emergency unit with fatigue, loss of appetite, diarrhea, swelling and redness on the legs. He was admitted to our hospital because his serum glucose level was $553 \mathrm{mg} / \mathrm{dL}$. Lower extremity Doppler ultrasonography (USG) showed bilateral acute deep vein thrombosis (DVT). It was thought that it might be associated with malignancy, especially the pancreas, due to DVT and diabetes newly diagnozed at advanced age. Ca19-9 (655 U/mL) was found to be high in the examinations. Other test results are given in Table 1. Abdominal USG revealed a $81^{*} 64 \mathrm{~mm}$ mass between the superior of the left kidney and the spleen. Gastroscopy and colonoscopy were unremarkable. In the abdominal computed tomography, there were homogeneously contrasting soft tissue appearances in the spleen lodge and anterior pararenal area, the largest of which was measured as $90 \times 67 \mathrm{~mm}$. A nodular soft tissue density of $13 \times 10 \mathrm{~mm}$ was observed in the neighborhood of the superior of the pancreatic corpus. Abdominal magnetic resonance imaging revealed solid mass lesions measuring $80 \times 65 \mathrm{~mm}$ in the spleen hilus and $46 \times 40 \mathrm{~mm}$ in the medial neighborhood and showing different intensities with the splenic parenchyma (Figure 1, 2). The patient was aspirated with two $22 \mathrm{G}$ from the paraaortic area with the help of endoscopic US, and smear and cell block were prepared. The liver was aspirated from a 50

Address for Correspondence: Tahsin KARAASLAN, Bezmialem Vakif University Faculty of Medicine, Department of General Surgery, İstanbul, Turkey

E-mail: drtkaraaslan@hotmail.com ORCID ID: orcid.org/0000-0002-1529-1790 
Table 1. Patient results

\begin{tabular}{|c|c|c|c|c|c|c|}
\hline & 13.03 .2018 & 31.03 .2018 & 02.04 .2018 & 23.04.2018 & Referans değer & \\
\hline Glucose & 183 & 500 & 183 & 159 & $70-105$ & $\mathrm{mg} / \mathrm{dL}$ \\
\hline BUN & 22 & 29 & 84 & 24.3 & $8.4-25.7$ & $\mathrm{mg} / \mathrm{dL}$ \\
\hline Creatinine & 0.96 & 1.46 & 3 & 1.07 & $0.72-1.25$ & $\mathrm{mg} / \mathrm{dL}$ \\
\hline Uric acid & 3.3 & & 11.2 & 3.3 & $3.5-7.2$ & $\mathrm{mg} / \mathrm{dL}$ \\
\hline T. Protein & 5.3 & & 4.9 & 5.5 & $6.2-8.1$ & $\mathrm{gr} / \mathrm{dL}$ \\
\hline Albumin & 3.0 & & 2.2 & 2.7 & $3.4-4.8$ & $\mathrm{~g} / \mathrm{dL}$ \\
\hline AST & 29 & 48 & 39 & 11 & $5-34$ & $U / L$ \\
\hline ALT & 61 & 49 & 50 & 11 & $0-55$ & $\mathrm{U} / \mathrm{L}$ \\
\hline ALP & 110 & 157 & 129 & & $40-150$ & $U / L$ \\
\hline GGT & 36 & 34 & 49 & & $12-64$ & $U / L$ \\
\hline LDH & 219 & 498 & 382 & 192 & $125-220$ & $U / L$ \\
\hline CK & 34 & & 189 & 15 & $30-200$ & $\mathrm{U} / \mathrm{L}$ \\
\hline T. BiL & 0.50 & 0.79 & 0.38 & 0.42 & $0.3-1.2$ & $\mathrm{mg} / \mathrm{dL}$ \\
\hline D. BIL & 0.17 & 0.16 & 0.28 & 0.20 & $0-0.5$ & $\mathrm{mg} / \mathrm{dL}$ \\
\hline Amylase & 90 & & 30 & & $20-160$ & $U / L$ \\
\hline Lipase & 9 & & 14 & & $8-78$ & $U / L$ \\
\hline Calcium & 8.2 & & 7.8 & 6.8 & $8.4-10.2$ & $\mathrm{mg} / \mathrm{dL}$ \\
\hline Magnesium & 2.27 & & & 1.37 & $1.6-2.6$ & $\mathrm{mg} / \mathrm{dL}$ \\
\hline Phosphorus. inorg & 2.0 & & & 2.1 & $2.3-4.7$ & $\mathrm{mg} / \mathrm{dL}$ \\
\hline $\mathrm{Na}$ & 136 & 134 & 142 & 138 & $135-145$ & $\mathrm{mmol} / \mathrm{L}$ \\
\hline K & 4.48 & 5.17 & 4.43 & 3.01 & $3.5-5.1$ & $\mathrm{mmol} / \mathrm{L}$ \\
\hline $\mathrm{Cl}$ & 107 & & 112 & 107 & $98-107$ & $\mathrm{mmol} / \mathrm{L}$ \\
\hline Folic acid & 5.4 & & 5.0 & & $3.1-20.5$ & $\mathrm{ng} / \mathrm{mL}$ \\
\hline B12 & 503 & & & & $157-883$ & $\mathrm{pg} / \mathrm{mL}$ \\
\hline Ferritin & 620 & & 3397 & & $21.81-274.66$ & $\mathrm{ng} / \mathrm{mL}$ \\
\hline CK-MB & & & 4.3 & & $0-7.2$ & $\mathrm{ng} / \mathrm{mL}$ \\
\hline Troponın I & & & 30 & & 0.40 & $\mathrm{pg} / \mathrm{mL}$ \\
\hline D-Dimer & & & 4449 & & $0-300$ & $\mathrm{ng} / \mathrm{mL}$ \\
\hline PTH & 63 & & 247 & & $15-68.3$ & $\mathrm{pg} / \mathrm{mL}$ \\
\hline CRP & 7.2 & 21 & 25 & 5.37 & $<0.5$ & $\mathrm{mg} / \mathrm{dL}$ \\
\hline Procalcitonin & 0.6 & & 335 & 2.94 & $<0.5$ & $\mathrm{ng} / \mathrm{mL}$ \\
\hline ESR & 15 & & 71 & & $<20$ & $\mathrm{~mm} / \mathrm{h}$ \\
\hline $\mathrm{Hb}$ & 9.8 & 9.65 & & 8.55 & $14.1-17.5$ & $\mathrm{~g} / \mathrm{dL}$ \\
\hline Hct & 10 & 30.3 & & 25.7 & $40-52$ & $\%$ \\
\hline MCV & 87 & 87 & & 85 & $80-97$ & $\mathrm{fL}$ \\
\hline WBC & 7500 & 14900 & & 7540 & $4.6-10.2$ & $10 * 3 / \mathrm{mL}$ \\
\hline PLT & 158.000 & 222.000 & & 158.000 & $142-424$ & $10 * 3 / \mathrm{mL}$ \\
\hline Glukagon & & & & $>500$ & $<209$ & $\mathrm{pg} /$ \\
\hline TSH & 0.26 & & & & $0.35-4.94$ & $\mathrm{mlU} / \mathrm{mL}$ \\
\hline CEA & 3.52 & & & & $0-5$ & $\mathrm{ng} / \mathrm{mL}$ \\
\hline Ca19-9 & 655.54 & & & & $0-37$ & $\mathrm{U} / \mathrm{mL}$ \\
\hline C-peptide & 2.82 & & & & $0.78-5.19$ & $\mathrm{ng} / \mathrm{mL}$ \\
\hline
\end{tabular}

AST: Aspartate transaminase, ALP: Alkali phosphatase, ALT: Alanine transaminase, GGT: Gamma-glutamyl transpeptidase, LDH: Lactate dehydrogenase, CK: Creatine kinase, T. BiL: Total bilirubin, D. BiL: Direkt bilirubin, Na: Sodium, K: Potassium, Cl: Chlorine, CK-MB, Creatine kinase myocardial isoenzyme, PTH: Parathyroid hormone, CRP: C-reactive protein, ESR: Erythrocyte sedimentation rate, Hb: Hemoglobin, Hct: Hematocrit, MCV: Mean erythrocyte volume, WBC: White blood cell, PLT: Platelets, TSH: Thyroid-stimulating hormone, CEA: Carcinoembryonic antigen, BUN: Blood urea nitrogen 
$\mathrm{mm}$ cyst and carcinoembryonic antigen (CEA), amylase and cytology were sent for evaluation. In the cyst fluid, amylase value was found as 15 and CEA as $0.9 \mathrm{ng} / \mathrm{mL}$. After the treatment of the patient was arranged and glycemic regulation was achieved, he was discharged for outpatient follow-up of biopsy results. However, the patient was admitted to the emergency service again and hospitalized in the clinic after twelve days because of deterioration in his general condition and swelling of his feet. The patient's previous biopsy result was evaluated as 'fine-chromotine neuroendocrine cell groups'. At this time, diarrhea and rashes on the lower extremities developed (Figure 3) and the patient was thought to have glucagonoma. Serum glucagon was $>500 \mathrm{pg} / \mathrm{mL}$ $(\mathrm{N}<209 \mathrm{pg} / \mathrm{mL})$. Surgery was recommended to the patient, but the patient and his relatives did not accept this recommendation. By the department of oncology, lanreotide was initiated to be administered every 28 days. Within days, the need for insulin decreased. The patient is still being followed up in the outpatient clinics of general internal diseases and oncology with lanreotide, glargine insulin and coumadin treatment.
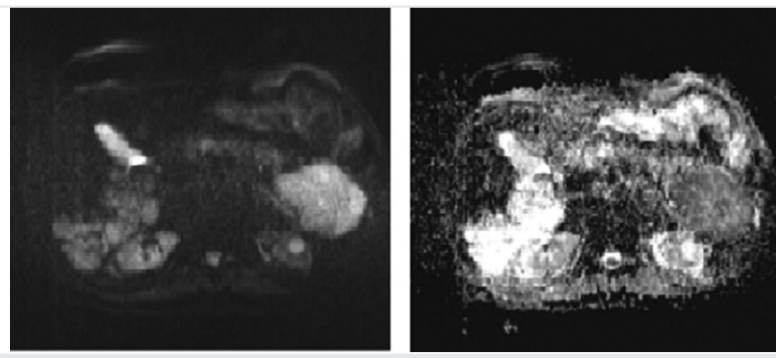

Figure 1. Abdominol MR image 1

MR: Magnetic resonance
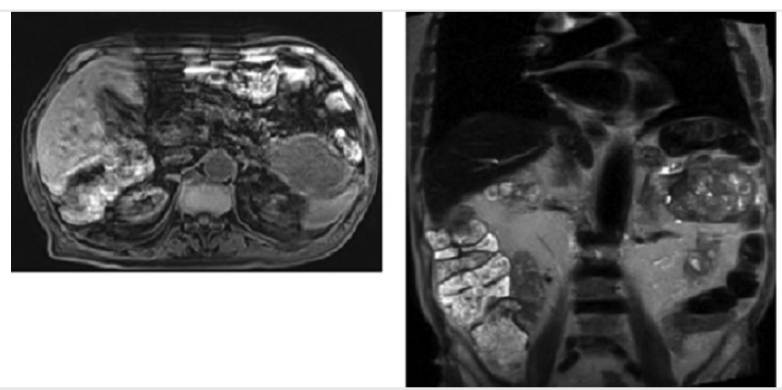

Figure 2. Abdominol MR image 2

MR: Magnetic resonance

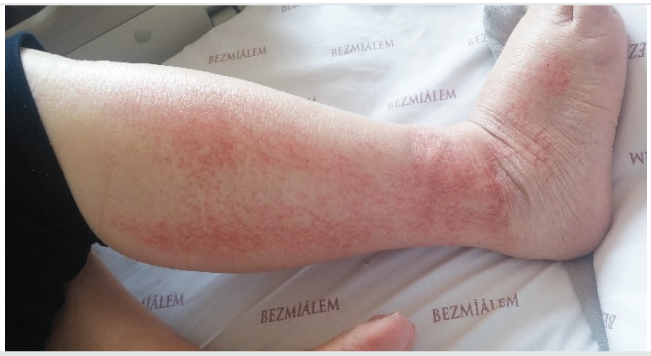

Figure 3. Lower extremity skin rash

\section{Discussion}

NET incidence is two per million and constitutes $0.5 \%$ of all cancers. It should be noted that NETs may coexist with other solid organ cancers. The gastrointestinal tract is the largest neuroendocrine system in the body, and NETs are often localized here. Gastroenteropancreatic NET (GEP-NET) cells are caused by diffuse endocrine system cells, which are phenotypically similar. These tumors are referred to as Neuroendocrine because they express proteins such as synaptophysin, neuron-specific enolase (NSE) and chromogranin A associated with neural cells. $65 \%$ of NETs occur in the gastrointestinal tract, $25 \%$ in the lungs, and the rest in other endocrine tissues. Clinical findings vary depending on the location of the NETs and the hormone that they secrete. Diagnosis is made by elevated blood glucagon level. The diagnosis is supported by the measurement of chromogranin-A (CgA) levels, 5-HIAA, CA19-9 and CEA levels. CgA has a sensitivity of $80 \%$ and specificity of $90 \%$ and has a better diagnostic value than 5-HIAA, NSE and pancreatic polypeptide. Plasma NSE identifies poorly differentiated NETs with $85 \%$ specificity and $70 \%$ sensitivity (5). Mitosis rate and ki-67 index are well below $2 \%$ in well-differentiated NETs and necrosis is not seen, whereas in poorly differentiated group, these rates increase above $10 \%$ and necrosis can be seen (6). Pancreatic NETs are also classified according to the hormones they secrete and they are called insulinoma, gastrinoma, glucagonoma, VIPoma. It can also be classified as local, regional and distant spread according to the extent of the disease. NETs may occur with metastases below $2 \mathrm{~cm}$. Similarly, the rate of metastasis was $50 \%$ at the time of diagnosis (7). The metastasis rate is determined by the organ from which the tumor originated. Glucagonomas are located in the distal pancreas at a rate of $85 \%$. In our case, the patient was examined considering GIS malignancy initially because there were weight loss, anemia, and DVT, and Ca199 was high (8). Abdominal imaging revealed a mass between the spleen and kidney; therefore, biopsy was performed under endoultrasonography. Meanwhile, basal-bolus insulin therapy for glycemic regulation and coumadin therapy for DVT were performed. After stabilization of the patient, he was discharged for outpatient follow-up. Then, the patient was brought back to the emergency unit due to deterioration of his general condition. Meanwhile, diarrhea and non-necrotic erythematous skin rash on the right leg were added to the complaints. In the immunohistochemical study of the previous biopsy, chromogranin $(+)$, synaptophysin $(+)$, pancytokeratin $(+)$, LCA $(-)$, ki 67 index was less than 1\%. Results were evaluated to be consistent with neuroendocrine tumor (Grade I). Glucagon level sent to support the diagnosis was found to be significantly higher (9). Surgical intervention was planned but was not accepted. As a result of the consultation with oncology, lanreotide treatment was planned (10). After the treatment, his general condition recovered and glycemic regulation was achieved. The patient was discharged for follow-up in the outpatient clinics of oncology and general internal medicine.

We wanted to emphasize that glucagonoma should be considered in cases with newly diagnosed diabetes and DVT, erythematous 
skin lesions, diarrhea and a mass in the abdomen and examinations for it should be performed.

\section{Ethics}

Informed Consent: Informed consent was obtained from the patient.

Peer-review: Externally peer-reviewed.

\section{Authorship Contributions}

Consept: T.K., C.K., Design: T.K., C.K., Data Collection or Processing: T.K., C.K., Analysis or Interpretation: T.K., C.K., Literature Search: T.K., C.K., Writing: T.K., C.K.

Conflict of Interest: No conflict of interest was declared by the authors.

Financial Disclosure: The authors declared that this study received no financial support.

\section{References}

1. Filik L. Nöroendokrin Tümörler. Güncel Gastroenteroloji 2012;16:133-5.

2. Yalçın K, Urakçı Z, Beştaş R, Uçmak F. Diffüz karaciğer metastazı ile başvuran bir hastada fonksiyonel olmayan nöroendokrin tümör: olgu sunumu. Akademik Gastroenteroloji Dergisi 2010;9:27-31.

3. Lawrence B, Gustafsson BI, Chan A, Svejda B, Kidd M, Modlin IM. The epidemiology of gastroenteropancreatic neuroendocrine tumors. Endocrinology and Metabolism Clinics of North America 2011;40:1-18.

4. Povoski SP, Zaman SA, Ducatman BS, McFadden DW. Dermatitis, glossitis, stomatitis, cheilitis, anemia and weight loss: a classic presentation of pancreatic glucagonoma. W V Med J 2002;98:12-4.

5. Nobels FR, Kwekkeboom DJ, Coopmans W, Schoenmakers HHC, Lindemas J, Herder WWD, et al. Chromogranin A as serum marker for neuroendocrine neoplasia: comparison with neuronspecific enolase and the alpha-subunit of glycoprotein hormones. J Clin Endocrinol Metab 1997;82:2622-8.

6. Yao JC, Hassan M, Phan A, Dagohoy C, Leary C, Mares JE, et al. One hundred years after carcinoid: epidemiology and prognostic factors for neuroendocrine tumors in 35.825 cases in United States. J Clin Oncol 2008;26:3063-72.

7. Borka K. Clinicopathological characterization of gastro-enteropancreatic neuroendocrine tumors. Magy Onkol 2018;62:90-7.

8. Han X, Wang D, Kuang T, Rong Y, Lou W. Glucagonoma syndrome: report of one case. Transl Gastroenterol Hepatol 2016;1:70.

9. Anne Couvelard, Olivia Hentic. Glucagonoma. In: Stefano LR, Fausto S, editors. Pancreatic Neuroendocrine Neoplasms: Practical Approach to Diagnosis, Classification, and Therapy. Springer International Publishing: Switzerland; 2015.pp.81-7.

10. Zeng J, Wang B, Ma D, Li F. Glucagonoma syndrome: diagnosis and treatment. J Am Acad Dermatol 2003;48:297-8. 